\title{
The Contract Motif in Western Literature and Identity Crisis*
}

\author{
Wensheng Deng \\ Dept. of Foreign Languages, Beijing Institute of Petrol-chemical Technology, China
}

\begin{abstract}
The paper explores the evolution of contract motif in the western context of literatures, and the relation of the contract to self-identity, based on the types of the contract, which is a symbol of identity. And then, it explains the roots of the identity crisis against modern people, and points out a possible way for them to dwell upon this world.
\end{abstract}

Index Terms - contract motif, identity, culture, spiritual faith

\section{INTRODUCTION}

It is known to us that a contract means at least two parties come to agree with a deal and draw an agreement between the parties. And a contract motif generally refers to the motif associated with the contract, written or spoken. The word "contract" is derived from Latin, "contractus", originally applied to ancient Greek philosophy and Roman laws, which means a deal with two parties or multiple ones to their satisfaction. The parties involved into the deal are equal, free and willing to participate, which implies the essence of the contract and is adopted in other fields like, religion, economy, political affairs and social communication. At the meantime, the parties are supposed to bear responsibilities and rights. But, the relation to deal with the parties concerned can be dated back to Hammurabi's Code in about 2000 B.C., in which the relation or concept of contract can be found 120 references. Nowadays, the Code has become a mine and significant to the evolution of western law.

In western art the contract motif is very popular. Researchers can find works concerned with the motif in literature, film, music, television, games, dance, and painting (http://en.wikipedia.org, 19/7/2013). The author of the paper intends to confine the discussion of the motif to literatures only. From The Holy Bible throughout Dr. Faustus written by Christopher Marlowe, The Merchant of Venice by William Shakespeare, The Social Contract by Jacques Rousseau, Faust by Johann Wolfgang von Goethe, Moby-Dick by Herman Melville, The Scarlet Letter by Nathaniel Hawthorne, and Catch-22, a postmodern work, somehow, by Joseph Heller, etc, readers can see the classics of the motif at hand easily. The contracts, which are adopted in the works mentioned above, are more or less transfigured in other work and are hard to be recognized at their first sight.

\section{The COVEnANT with GoD}

The first and foremost covenant of human kind is signed between God and his chosen peoples Hebrews, which is recorded in Pentateuch of The Old Testament, the first part and parcel of The Holy Bible; the other one is The New Testament; Pentateuch is regarded as Torah, a kind of laws, in Judaism. And from the titles of The Old/New Testament people know that they have something to do with the covenant, which means the testament or pact promised or signed between God and his followers. First, God promise to Abraham, the ancestor of Hebrews, that He'll give his tribes through Abraham a promised land, flowing milk and honey, and "That in His Seed All Nations should be blessed"; God's covenant with the Hebrew Nation is:

That, if they would Faithfully Serve Him,

They would Prosper as a nation:

That, if they Forsook Him, and served Idols,

They would be Destroyed as a nation (Halley, 1965, p.31).

By God's promise and covenant, God chose the Hebrews to serve Him, and He will bless them; otherwise, He would give them punishment accordingly. Because the Hebrew as a nation is in its infantile stage, God has inscribed Ten Commandments (Deuteronomy 5: 7 21) on two tablets and handed them to Moses, a leader of the Hebrew. The Commandments are a series of rules and regulations to control the Hebrews' behavior morally and ethically, i.e., which stress the morality and ethicality. That is God's original intention to make the codes for the Hebrews. The proof which signifies a Jewish man has signed a pact with God is their circumcision. The mark is taken as a proof to determine that the pact was made. It was also believed that on the spot where the mark was left, the marked person could feel no pain because of his faith in God. Throughout the two parties of the covenant, God is almighty; the Hebrew nation is fragile; fortunately, the strong is kind to the fragile. And we may sum up the whole procedures of the covenant as "a pact with

\footnotetext{
* The paper is sponsored by China Center for Foreign Language Textbook \& Teaching Research, Shanghai Foreign Language Education Press.
} 
God"; we hold that it is a primordial type of the contract motif. No wonder that Jews, the offspring of the Hebrews, have the born tendency to sign a contract with other parties in a deal, which is evolved into a part of the heritage of the national culture. As to The New Testament, it is said that a new Messiah, Jesus Christ, will come to rescue his followers and to establish a Heavenly Kingdom in the final. Either the new or old testaments, spoken or written, denotes the concept of human vs. God, rooted in Judaism and Christianity, which is of great significance in the respective religious culture. Because, according to Judaism or Christianity, the concept of which everybody is equal before God is the motif source of the concept of which everybody is equal before the law till today. To some extent, Judaism or Christianity lays a foothold to the modern legal system. But, from another viewpoint to consider the testaments, one party is stronger than the other one, which has also set up a sample for others to follow. Probably the Hammurabi's Code was affected by Abraham's laws, or vice versa (Halley, 1965). So a new relation throughout the contract of the Code is formed. What's worse is the relation of the Code is imposed upon the labors by force. Then, a second type of the contract motif is evolved into the kind of strong vs. the weak. Consequently, people's identity is differentiated under the altered contract of the code, like the Hammurabi's Code.

Understandably, people wonder why the Hebrew has signed the covenant with God. As we know that Abraham's time is in the primitive stage of human civilization, the primitive peoples are full of admiration and cult of the world. They think everything over the world is spiritual like them, such as wind, cloud, flood, rainbow or even lightning etc. They try to communicate with the objects of the world in a unique spiritual way. Of course, we modernists regard their behaviors as mythology, which is ancient science for the primitive peoples. Therefore, in The Holy Bible the clouds over Mt. Sinai, the Flood, the New Rainbow, the Draught or the endless fire, and the like are considered as the signs created by God. Then, the first type of the compact is bound to contact with god, for who is thought to be a protector of the tribes.

\section{THE DEAL WITH THE DEVIL}

If we take a look into Dr. Faustus and Faust, we'll know that they have something in common, i.e. the plot of the two plays is closely connected with a devil. The hero of the works signed a pact with a devil, Mephistopheles. In $D r$. Faustus, weary of the sciences, Faustus turns to magic and calls up Mephistopheles, with whom he makes a compact to surrender his soul to the Devil in return for 24 years of life; during these Mephistopheles shall attend on him and give him whatever he wants. Then follows a number of scenes in which the compact is executed, notable among them the calling up of Helen of Troy, where Faustus addresses Helen in the well-known line: 'Was this the face that launched a thousand ships...' The anguish of the mind of Faustus as the hour for the surrender of his soul draws near is poignantly depicted (Drabble, 1985). In the general the character of Dr. Faustus is a tragedy.

In Faust of Goethe, God and Mephistopheles make a bet: The Devil, Mephistopheles, believes that the ruin of the soul of Faust would be affected by his temptation; God is confident that the Devil will fail. Then the Devil's plot against Dr. Faust is put into action. Disillusioned with the world and despairing to life, Faust enters into a compact to become the devil's servant if he should exclaim, of any moment of delight procured for him. Then follow the attempts of Mephistopheles to satisfy Faust. Because Faust fails to get love and perform his talents for his country, he is led to the Greek kingdom of classical beauty, gets married with Helen, but fails to live a harmonious life with Helen for their son Euphorion's death. Therefore, Faust has to work the land with the Devil's help. Finally, satisfied in the consciousness of good work done, he cries to the fleeting moment, 'Stay, thou art so fair', and falls dead. His soul is borne away by angels (Drabble, 1985). In the play Faust's endless pursuit of his ideals is instructive and symbolic. Faust of Goethe is different from Faustus of Marlow; the former is kind of positive, the latter passive.

Tracking down the plot of the two plays, we find that the subject of Marlow and Goethe, was a wandering conjuror, who lived in Germany about 1488-1541 and is mentioned repeatedly in various documents of the period, and is said to have sold his soul to the Devil (Drabble, 1985). From Abraham's date, about 2000B.C, to the Middle Ages, 1600 A.D., the tales of the contract motif is transfigured from the archetype, a pact with God, the relation of human vs.God, into a pact with the Devil, the relation of human vs. the Devil; one party of the contract, God, is substituted by the Devil. In the mediaeval eras the folks of Europe are religious and superstitious, which is said to be dark ages with one religion, Christianity. People at the times are illiterate, let alone make use of the science to observe the world. People still believe that there are devils, evil spirits or something mysterious in the world. One of the horrible cases is women with leprosy. The medievalists think that the women are possessed with evil spirit. And they are supposed to be burnt to death. Actually the mysterious spirit is characterized of the medieval Ages. No wonder that it is in the Middle Ages that the folktales about the Devil are derived.

The altered type of the contract motif, a pact with the Devil, gets popular in the world literatures after the Ages. For instance, The Picture of Dorian Gray, novel by Oscar Wilde, Pani Twardowska, poem by Adam Mickiewicz, St. John's Eve, short story by Nikolai Gogol, The Devil and Tom Walker, short story by Washington Irving, they adopted the altered form of the motif in a less or more extent, which prove it to be influential.

\section{ThE BOND WITH AN EVIL-HEARTED PARTY}

Another variant of the motif appears among the world works of classics, i.e., a pact with an evil-hearted party. The 
Merchant of Venice by William Shakespeare and Moby-Dick of Herman Melville are good cases in point. One of the former's plots is that Antonio, a Venetian merchant, signed a bond with Shylock, a Jewish usurer, to borrow 3,000 ducats from the usurer, in which, if the sum is not repaid at the appointed day, Antonio shall forfeit a pound of flesh. But, due to the time expired, news is said that Antonio has not been repaid because of his vessels wrecked, and Shylock insists to claiming his pound of flesh. Thus, Shylock is thought to be merciless, bloody and a wild wolf. Fortunately, Antonio is rescued by Portia, who is disguised as a law judge; she pronounces that Shylock get the pound of the flesh without a ounce more or less and a drop of blood, by explaining the article of the bond word for word. Obviously, Shylock is stubborn, merciless and played by his opponent party of the bond, headed by Antonio and Portia. The two parties of the contract are Antonio and the evil-hearted Shylock. In Moby-Dick, Captain Ahab of the Pequod, a whaler, recruits new employees by signing a pact to capture whales, such as Ishmael and Queequeg, who are two of the signed employees. Ahab nails a golden coin to the mask as a reward to the man, who first has got sight of Moby-Dick, a giant white whale. Every employee's profit is tied to the bond in the Pequod under Ahab's hand. Ahab is not only cold-blooded, materialistic but also a good manager. We have to admit that Ahab's management of the compact is a sort of modern way. Therefore, the employees are taking great pains to work for him. Unconsciously, the two sides, the management and the labors reach an agreement. The bilateral relations between the two sides are not equal in the least, of which the evil-hearted party is controlling the pact. Only the type of contract is changed a little bit; the place of the Devil is replaced by an evil-hearted man; in The Merchant of Venice, the evil-hearted party is Shylock, in Moby-Dick, Ahab. In the commercial era of William Shakespeare or Herman Melville, which the capitalist economy begins to develop rapidly, a man easily tends to be a servant of money or wealth, like Shylock, a slave of money, and Ahab, an attendant of wealth. Hence, the mode of the contract has something to do with money or wealth, which is a product of the history and times, and the work mirrors the unfair relation between the parties.

\section{The Universal Agreement}

A forth variant of the contract motif is a series of rules and regulations universally accepted by residents in a living community. Apparently, there is no party to sign the rules, whether written or spoken. They are formed among the native peoples in the times immemorial and passed down generation by generation, which are a kind of instructions to regulate the residents' behaviors. And whoever violates the rules, he/she is bound to be punished. And so, The Scarlet Letter of Nathaniel Hawthorne, an American novelist, can be interpreted this way, i.e. a kind of the motif. In the novel an aged scholar sends his young wife, Hester Prynne, to establish their home in Boston. When he arrives two years later, he finds Hester in the pillory with her illegitimate child in her arms. She refuses to name her lover. The husband conceals his identity, assumes the name Roger Chillingworth, and in the guise of a doctor seeks to discover her paramour. He discovers that the Rev. Arthur Dimmsdale is the father of Hester's beautiful, mischievous child, Pearl. In the plot the readers of the novel get to know that the wife Hester is an adulteress, whose behavior is a violation of the regulations of the region, Boston, especially in Puritan times, whose doctrines inhibit all kinds of instincts. Residents of the area agree to sentence to Hester to wear a scarlet letter A, signifying adultery. Committing the violation, Hester can not be exceptionally exempted from the punishment, for who is a member of the region and should bear the responsibility as well. Here in the story the contract is a loosen promise accepted by all the community members; the type of the contract is that every one is a participant and a party of the contract, based on a unanimous agreement, somewhat like a kind of public regional law. As to the type of universal agreement, the participants are supposed to abide by it willingly and conscientiously only if you are a member of the community. The promise or contract is the original mode of international public law, for which is accepted by international communities. From the novel we see its background is set in Boston, and the immigrants there mainly are from England, most of who have accepted Puritanism before they come to the new world. To the Puritans, labor, moral and inhibition of instincts are their goals to purify them. So, Max Weber, a German thinker, put forward the thesis, the Puritan ethics is the power to develop the capitalism in America; he's true indeed. And besides Boston, New England and other coastal regions of the U.S.A. are abiding by the Puritan doctrines. Hester, as a Puritan, she is bound to accept the moral code.

\section{THE COMPACT WITH THE INSTITUTION}

There is a fifth type of the contract presented realistically and ridiculously in novel Catch-22 written by an American novelist Joseph Heller. In the story Joseph tells us a regulation, called Catch-22: Any flier who is insane is allowed to be free from flying a mission and be sent to U.S.A, only on the condition that he must apply to his boss in person; at the meantime, if he is aware of the hazards of flying a mission and he applies to his boss to be free from flying, he is regarded sane and he should carry on flying more missions. If a flier has finished his missions demanded, he is able to return to America; but he must absolutely obey his boss. A careful reader of the story would find the trap hid in the military discipline. Actually no one is able to escape from the law, for which asks every pilot obey his boss absolutely. The logical formula hidden under the Catch-22 is: A is A, and A is not A, which is a clear violation of the logical laws of exclusion. And A is nowhere and is nothing according to the formula. For Captain John Yossarian of the U.S. air force in the story, after having experienced grisly events and observing his fellow officers being ridiculous in their lust for promotion, his tricks to avoid further combat is to pretend to be insane, he turns up naked at awarding ceremony. After 
reading the story, a kind of absurdity and ridiculousness is presented to most of the readers. And from the foothold of the contract, we see the two parties of the discipline are neither fair nor square. One party is an institution of the country's machine, air force, whose mission is to secure the safety of the country; the other party is the miserable pilot. In the contract the air force as a party is powerful, which stipulates the most majority of rights and responsibilities; in contrast to it, the other party, individual pilot, is fragile, whose fate is predominated and hard to change. In essence, the type of the contract is not equal in the beginning. Ironically the mode like the Catch-22 gets developed in modern firms. So most of the modern employees have to accept the mode, their living condition or index of happiness is getting worse, which exactly proves what Martin Heidegger, a modern German philosopher, said that the living condition of the modernists is anguish and anxiety.

As to the setting of the novel, it is in a small island Pianosa of Italy during World War II. The Allied are waging wars against the Axis. American Air forces are the pioneers of the war. Seemingly they are sacrificing their lives to the country. Ironically, a lot of men are taking the advantages of the wars to gather treasures or be promoted. They try every conceivable means to snatch economic and political capital even by helping the warring opponents. The pilots are just like the chess pieces played by their officer to realize their intents. And the Catch-22 is one of the ways. On one hand average individuals, as a party, are attracted to commit themselves to a noble venture, encouraged to sacrifice the life in vain instigated by a justified power, as another party, which can be a company, an organization, or a branch of the country. On the other hand, somehow the contract is a sort of trap for the ordinary individuals. They can hardly escape from it. Only their death is the way for them to be liberated form the trap. Karl Marx, a German philosopher, says it is capitalist that exploits every worker to his last blood. What Marx says is just the situation in Catch-22. So, the author thinks the novel is realistic to some degree.

\section{THE BRAND-NEW CONTRACT}

The brand-new form of the contract is born in France from The Social Contract written by Jacques J.Rousseau, one of the advocators of the modern country. He advocates an equal contract among citizens, which means the parties evolved into the contract is equal regardless of his birth, background and rank. He writes that every one is born to be equal, which implies the relation of the party signing the contract is equal (Rousseau). The equal foothold of the parties is the key to the new contract, which is the party's true appeal as well. We know that France is a rank-oriented country before French Revolution in 1789. To overthrow the contemporary ruling class, the French revolutionists call for "liberty, equality and fraternity" to unite the common mass. It is the slogan that attracts the mass to participate the Revolution. After the Revolution France starts off its road to build a modern country. The new model of the contract is echoed in the new world across the Atlantic Ocean, i.e. the U.S.A. is the practice of the French ideal. Hence, people remark that Europe puts forward new ideas; America actualizes them. In the new model of contract both parties, citizen and country, bear rights and responsibilities respectively.

\section{THE PACT AND THE CRISIS OF IDENTITY}

Though a kind of new contract, a new relation of citizen, is raised and formed its basic shape more than 200 years ago by European thinkers, modern people feel puzzled and perplexed more and more today, which indicates the new social contract is imperfect as well. Today's problems focus on their being lost in the direction of life and in the sense of belonging somewhere. In a word, they have lost their identity throughout this world.

The crisis of identity, which has stood out in the mid- $19^{\text {th }}$ century, lies in the western civilization itself. The scientific progress and advancement of the civilization, which human beings have been seeking for since the time created human by God, haven't solved the mental problem of human beings. The scientific rationality turns out to be a double-edged sword. The stricken-poverty is partially eradicated in some countries temporarily; however, the spiritual desolation of "waste land" has approached us without being noticed. The German thinker of Spengler declares that the western civilization is declining to its end. Especially, after Nietzsche, a talented philosopher of Germany, pronounces that the God is dead, and everything is supposed to be evaluated again. The westerners' spiritual prop is collapsed. The cultural earthquake has shattered people's faith. The author of the paper hold that it is most of modern people who have broken the first contract, i.e., the compact with God, or in other words, they don't believe a kind of spiritual faith, and only seek for money, fame, rank or physical pleasure, their confusion and chaos are inevitable. On the contrary, the Jews, descendants of the Hebrew, they not only have not lost their identity, have not assimilated by other races, but also have survived all the disasters of the Diaspora for more than 2000 years. The key factor for the Jews to achieve success is that they have persisted their old covenant, which signifies their national identity. So, a kind of spiritual bond is the guarantee to secure self-identity.

The crisis is also led by the loss of the pacts. It is easy to understand that the modern people are reluctant to keep the pact with a Devil, an evil-hearted man, a non-humanitarian institution. After the Renaissance, people begin to lose the faith of God, to unmask the mystery of the world for the rapid scientific progress; so the relation to a Devil is lost quickly. With the capitalist market economic expansion over the world, money becomes the king of the world, which conflicts against "equality, liberty and fraternity"as a principle for a man's growth. Predictably, the bondage with an evil-hearted man is abandoned. In the modern world, the branch institutions of the country take advantage of the 
countrymen to perform a sort of ism. After they are aware of some deception, the modern people will escape from it and wildly protest against it, and feel lost or beat, they become a lost/beat generation. As a kind of the consequence, they are called a generation with problems.

The crisis is caused as well because of the human's fragility. William Shakespeare (2000) said, "Frailty, thou name is woman!" From the denotation, it refers to a woman's weakness, but it can be true all the same while referring to all human beings indeed. Hester Prynne, isolated and lost contact with her husband for years, falls into love with a priest, which violates the unanimous agreements and Puritan doctrines. She can not reject the instinct and inevitably leads to her crisis of identity.

The unstable status of the modern men and brevity of life are the roots of the crisis. Generally modernists have not signed an eternal contract with some party. Their status is instantly changed time after time. To their fear, they are not willing to sign an everlasting compact, for which means they will either lose freedom, change, and passion or live a repeated, boring, tedious, hopeless life. People are afraid to follow Sisyphus' step to do a repeated, mechanical work in life (Hamilton, 2011). It is a paradox for human beings to live on.

\section{CONCLUSIONS}

The contract and the identity are a couple of contradictions. On one hand, a man desires an identity to dwell upon the world; otherwise he is invisible or hidden somewhere, which is unfair to everybody; and a contract is a good way to mark one's identity in a community. On the other hand, human being is born to be a lover of liberty and equality; he dislikes any restriction upon him. To find the joint to balance the two sides well, it is a life-long goal for a man to pursue, from the motto inscribed on the pillars of Greek Parthenon, "Know thyself!", which implies the life's ultimate appeal, to the ancient wise Greek, Diogenes of Sinope, who has showed us the way to live a happy free life, in fact we have too many examples to follow, and unfortunately, we still don't know where we are going to but on the way to grope.

\section{REFERENCES}

[1] http://en.wikipedia.org/wiki/Deals_with_the_Devil_in_popular_culture (accessed 19/5/2013).

[2] Halley, Henry. (1965). H. Halley's Bible Handbook with the King James Version (23 ${ }^{\text {rd }}$ edition), Michigan: Halley's Bible Handbook, Inc ${ }^{\mathrm{B}}$., Zondervan, Grand Rapids. See Deuteronomy 5: 7 21.

[3] Drabble, Margaret. (1985).The Oxford Companion to English Literature (5 ${ }^{\text {th }}$ edition). New York: Oxford University Press.

[4] Hamilton, Edith. (2011). Mythology (oversize edition).New York: Hachette Book Group.

[5] Rousseau, Jacques J. (2011). He, Zhaowu (tran.). The Social Contract. Peking: The Commercial Press.

[6] Shakespeare, William. (2000). Hamlet. Peking: Foreign Economy and Trade University of China.

Wensheng Deng, born in Anhua County of Hunan Province of China in 1967, received his M.A. in literature from Central South University, China, in 2002, and was further trained his academics at Harding University of U.S.A. from 2007 until 2008. And now, he is Associate Professor of Anglo-American literature in Dept. of Foreign Languages, Beijing Institute of Petrol-chemical Technology, China. His studies cover Comparative Literature, Translation Studies and Politics.

Mr. Deng is a member of the Chinese Association of Foreign Language Teachers. And he has published more than thirty papers related with literature, translation, politics, and the like. 